\title{
Mini-implant and Nance button for initial retraction of maxillary canines: A prospective study in cast models
}

Flávia de Moraes Arantes', Juliana Kina², Matheus José Bueno Gonçalves ${ }^{3}$, Júlio de Araújo Gurgel ${ }^{4}$, Omar Gabriel da Silva Filho ${ }^{5}$ Eduardo César Almada Santos ${ }^{6}$

Objective: Bone anchorage is a key factor for the successful management of some malocclusions for it allows the application of continuous forces, decreases treatment time and is independent from patient compliance.

Methods: The goal of this work was to establish a dental model comparison in order to measure the anchorage loss after the initial retraction of upper canines between the two groups. Group A used mini-implants and Group B used Nance button. All patients had two models cast (M1 and M2). The first models were taken on baseline (M1) and the other models were taken after canine retraction (M2).

Results: All measurements were pooled and submitted to statistical analysis. In order to verify the inter-examiner systematic error a paired t-test was performed. Dahlberg's formula was used to estimate the casual error. For comparison purposes between Before and After stages, a paired t-test was done. For the comparison between mini-implant and Nance button groups, a Student t-test was applied. All tests adopted a 5\% (p<0.05) significance level.

Conclusion: No statistically significant difference was observed between the two groups when measurements and comparisons to assess molar anchorage loss after canine initial retraction were performed. Two different anchorage systems were applied on dental models (mini-implants and Nance's button) for each group.

Keywords: Orthodontic anchorage procedures. Dental casting technique. Orthodontics.

\footnotetext{
${ }^{1}$ Specialist in Orthodontics, UNESP. PhD in Orthodontics, FOA-UNESP.

${ }^{2}$ Specialist in Orthodontics, UNESP. MSc and Orthodontics, UNESP.

${ }^{3}$ Graduated in Dentistry, UNESP. Specialization student of Orthodontics, São Paulo General Hospital .

${ }^{4}$ Full Professor, Centro Universitário do Maranhão. Assistant Professor and PhD, UNESP.

${ }^{5}$ Orthodontist, Hospital for Rehabilitation of Craniofacial Anomalies, University of São Paulo (HRAC-USP).

${ }^{6}$ Adjunct Professor of Orthodontics, UNESP. Invited Professor at Washington University.
}

\begin{abstract}
How to cite this article: Arantes FM, Kina J, Gonçalves MJB, Gurgel JA, Silva Filho OG, Santos ECA. Mini-implant and Nance button for initial retraction of maxillary canines: A prospective study in cast models. Dental Press J Orthod. 2012 July-Aug;17(4):134-9.
\end{abstract}

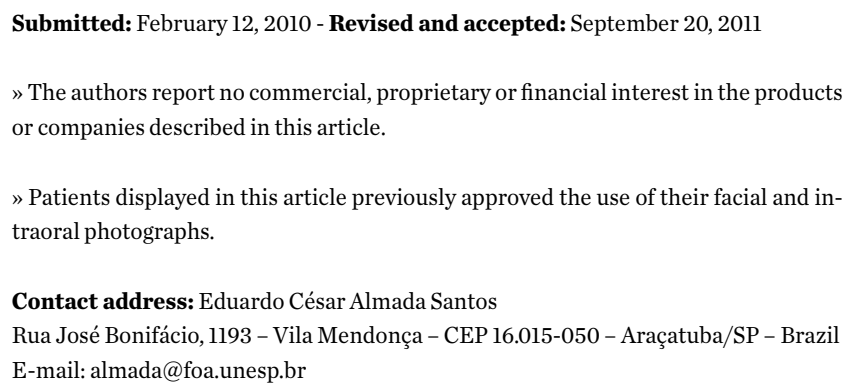

Contact address: Eduardo César Almada Santos

Rua José Bonifácio, 1193 - Vila Mendonça - CEP 16.015-050 - Araçatuba/SP - Brazil E-mail: almada@foa.unesp.br 


\section{Mini-implante e Botão de Nance para retração inicial de caninos superiores: estudo prospectivo em modelos}

Flávia de Moraes Arantes', Juliana Kina², Matheus José Bueno Gonçalves ${ }^{3}$, Júlio de Araújo Gurgel ${ }^{4}$, Omar Gabriel da Silva Filho ${ }^{5}$, Eduardo César Almada Santos ${ }^{6}$

Objetivo: a ancoragem óssea é fundamental para o sucesso do tratamento de algumas más oclusões, pois permite a aplicação de forças contínuas, diminui o tempo de tratamento e independe da colaboração do paciente.

Métodos: o propósito desse trabalho foi comparar, por meio de modelos dentários, a perda de ancoragem após a retração inicial de caninos superiores entre dois grupos. O grupo A utilizou o mini-implante enquanto o grupo B utilizou o Botão de Nance. Para todos os pacientes foram realizados dois modelos $\left(\mathrm{M}_{1}\right.$ e $\left.\mathrm{M}_{2}\right)$. Os primeiros modelos foram realizados ao início $\left(\mathrm{M}_{1}\right)$, e os outros ao final da retração inicial de canino $\left(\mathrm{M}_{2}\right)$.

Resultados: todas as medidas foram tabuladas e submetidas à análise estatística. Para verificar o erro sistemático intraexaminador foi utilizado o teste t pareado. Na determinação do erro casual utilizou-se o cálculo de erro proposto por Dahlberg. Para comparação entre as fases Início e Após, foi utilizado o teste t pareado. Para a comparação entre os grupos de mini-implante e Botão de Nance, foi utilizado o teste $t$ de Student para medidas independentes. Em todos os testes foi adotado nível de significância de $5 \%(\mathrm{p}<0,05)$.

Conclusão: ao se medir e comparar em modelos dentários a perda de ancoragem dos molares após a retração inicial de canino utilizando-se dois sistemas de ancoragem distintos (Mini-implante e Botão de Nance), pôde-se observar a inexistência de diferença estatisticamente significativa entre os dois grupos.

Palavras-chave: Procedimentos de ancoragem ortodôntica. Modelos dentários. Ortodontia.

\footnotetext{
${ }^{1}$ Especialista em Ortodontia, UNESP. Doutora em Ortodontia, FOA-UNESP.

${ }^{2}$ Especialista em Ortodontia, UNESP. Mestre e Doutora em Odontologia, UNESP.

${ }^{3}$ Graduado em Odontologia, UNESP. Aluno de especialização em Ortodontia, Hospital Geral de São Paulo.

${ }^{4}$ Professor titular do Centro Universitário do Maranhão e Professor Assistente Doutor da Universidade Estadual Paulista Júlio de Mesquita Filho.

${ }^{5}$ Ortodontista do Hospital de Reabilitação de Anomalias Craniofaciais da Universidade de São Paulo (HRAC-USP).

${ }^{6}$ Professor Adjunto da disciplina de Ortodontia, UNESP. Professor convidado da Universidade de Washington.
}

\begin{abstract}
Como citar este artigo: Arantes FM, Kina J, Gonçalves MJB, Gurgel JA, Silva Filho OG, Santos ECA. Miniimplant and Nance button for initial retraction of maxillary canines: A prospective study in cast models. Dental Press J Orthod. 2012 July-Aug;17(4):134-9.
\end{abstract}

Enviado em: 12 de fevereiro de 2010 - Revisado e aceito: 20 de setembro de 2011

» Os autores declaram não ter interesses associativos, comerciais, de propriedade ou financeiros, que representem conflito de interesse nos produtos e companhias descritos nesse artigo.

» Os pacientes que aparecem no presente artigo autorizaram previamente a publicação de suas fotografias faciais e intrabucais.

Endereço para correspondência: Eduardo César Almada Santos Rua José Bonifácio 1193 - Vila Mendonça - CEP 16.015-050 - Araçatuba/SP E-mail: almada@foa.unesp.br 


\section{INTRODUCTION}

Anchorage is a key factor for a successful orthodontic approach. ${ }^{19}$ Although orthodontic treatments have been quite successful, some limitations should be observed towards certain movements and much has been done to accomplish an effective patient cooperation. ${ }^{5}$ Over the last two decades mini-implants have been introduced in orthodontic clinical practice with the purpose of providing anchorage and have shown to be quite a promising option. ${ }^{3,4,16,17}$ The use of a stable anchorage eliminates undesirable movements upon anchoring teeth and replaces traditional procedures such as the headgear, what allows for continuous force application leading to a shorter treatment time., ${ }^{1,14}$

The intensity of the load may vary from one type of movement to the other. Regarding retraction movements, the load applied differs from initial canine retraction to anterior retraction. For initial retraction, the load ranges from $50 \mathrm{~g}^{5,11}$ to $100 \mathrm{~g}^{5,20}$ whilst for anterior retraction it ranges from 150 to $200 \mathrm{~g},{ }^{5}$ allowing for even higher load intensities such as $200 \mathrm{~g}$ and $300 \mathrm{~g}^{5,9,11,12}$ with good results and without any jeopardise to the root structure or the periodontium. For molar mesialization movements towards the gaps of prematurely lost teeth, Roberts ${ }^{5,15}$ suggests the use of $408 \mathrm{~g}$ for moving second and third molars.

Mini-implants may be self-piercing ${ }^{6}$ or selftapping (with and without previous perforation procedure, respectively). Some authors ${ }^{7,18}$ state that the self piercing mini-implants are more traumatic since this procedure induces physical pressure and micro fractures in the surrounding bone structure, possibly leading to periosteal or endosteal injury. However, other professionals argue that the self-tapping mini-implant system causes larger bone trauma due to the frictional heat created by the threads during the perforation previously performed. ${ }^{18}$

With regards to the time for load application there is no consensus. Many periods have been studied, varying from immediately after to 2, 4 or 6 weeks later, ${ }^{5,10,12}$ and the implant loss, in none of the works, was ever related to the waiting interval.

In an attempt to be less reliant on patient cooperation and to be able to achieve new anchorage solutions in orthodontic treatments, mini-implants are recommended for adult patients in need of maximum anchorage (intrusion, extrusion, retraction and protraction) who are reluctant to use extra-oral braces as well as in cases where the orthodontic anchorage cannot be accomplished due to tooth losses.

For the reasons above listed and for the indiscriminate clinical application of mini-implants the related anchorage loss there came the interest for this subject. The goal of this work was to use dental models to establish a comparison, between two groups, of the upper first molars anchorage loss after upper canines initial retraction. While Group A used mini-implants, Group B used the conventional intraoral anchorage technique. The null hypothesis to be tested is that both anchorage systems present similar results.

\section{MATERIAL AND METHODS}

In this experiment 18 patients were selected, average age 15 years old, randomly divided between two groups, with 9 subjects each (A and B), out of the screening for orthodontic treatment at Araçatuba School of Dentistry - UNESP. The inclusion criteria for the research were:

a) Patients with a balanced facial pattern. ${ }^{15,16}$

b) Patients in the post growth spurt phase.

c) Patients presenting upper anterior crowding, demanding upper and lower pre-molars extractions (Fig 1 ).

Orthodontic therapy for patients with upper anterior crowding from Group A was carried out by the use of self-tapping 1,6 x 10mm titanium mini-implants from SIN (Sistema de Implante, São Paulo, Brazil).

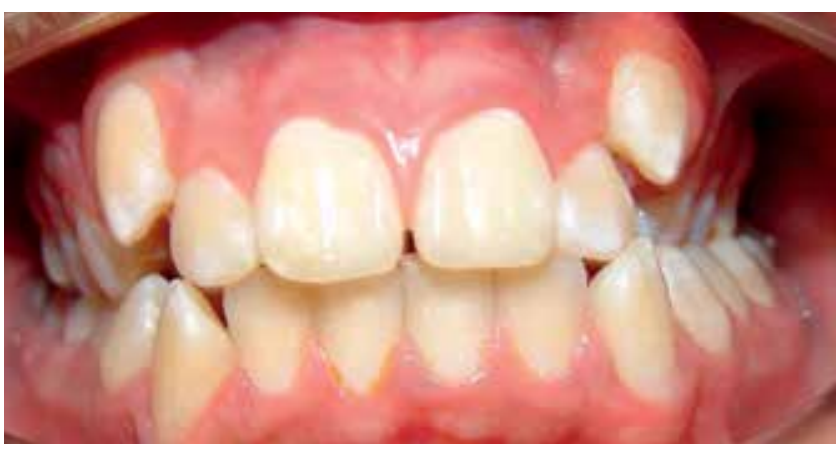

Figure 1 - Intraoral view of a patient with upper anterior crowding. 
Squeff et al, ${ }^{18}$ after determining topography, archetype and torque test of some SIN mini-implants, stated that all tested mini-implants were adequate for clinical application as an adjunct to orthodontic anchorage.

Implants were inserted both sides into the upper alveolar bone, between the second pre-molar and first molar, over attached gingiva. In order to prevent root lesions, they were inserted in the interseptal areas of these teeth, guided by the periapical radiographs, taken under the parallelism technique. After implant insertion, the first pre-molars were extracted, with an immediate onset of $150 \mathrm{cN}$ load applied over the canines. In the lower arch, the lingual arch was used as anchorage. Alignment and levelling were performed with Edgewise fixed appliance, according to Capelozza prescription, Standard I (Abzil 3M, São José do Rio Preto, Brazil).

Group B received orthodontic treatment using Nance button as the anchorage system for the upper arch and Nance lingual arch for the lower teeth, both manufactured using a $0.9 \mathrm{~mm}$ wire (Morelli). The anchorage systems were first incorporated followed by Edgewise appliance fixation, according to Capelozza prescription, Pattern I (Abzil 3M), and subsequent extraction of the first pre-molars. Initial canine retraction under $150 \mathrm{cN}$ load per side was immediately started.

All patients had two impressions taken: Ml model (taken at baseline) and M2 model (taken after the initial canine retraction). This initial canine retraction phase was chosen due to the great anchorage loss that usually takes place during this treatment stage $\mathrm{e}^{4}$ and also for the clinically satisfactory incisors alignment. This work had no aim to assess anterior retraction, since during that treatment stage some anchorage loss was needed concomitantly to the group retraction

Plaster casts were obtained after an impression was taken with Kromopan alginate, batch number 0155300130.103514 (Lascod SpA Florence Italy) and water, under a $1 / 1$ proportion. Impressions were then poured with Durone V stone, batch 539589 (Dentsply Indústria e Comércio Ltda Petrópolis, RJ Brazil) and water under the proportion of $19 \mathrm{~mm}$ of water for each $100 \mathrm{~g}$ of plaster, in order to reproduce the dental structures as precisely as possible.

Aiming optimize the measurement of the dental models, which are tridimensional by nature, all upper models underwent a photographic scanning with an HP scanner (Scanjet G4050 China), being transferred to a two-dimensional and flat image. No models needed to be cut or trimmed since only the occlusal surface touched the scanner avoiding undesired tilting.

Both upper models (baseline and post canine initial retraction) from each patient were scanned together in order to avoid possible dimensional changes due to different scanning process. Moreover, models from each patient were scanned one at a time (Fig 2).

Figure 2 - Upper models (baseline and post canine initial retraction) were scanned separately for each patient.
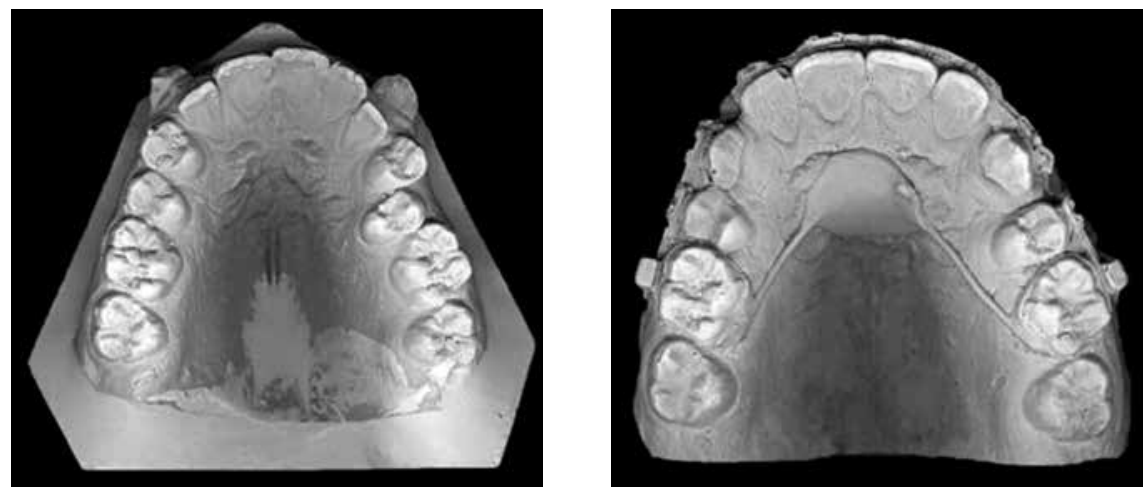
The images obtained from the scanned models were transferred in the format of a Microsoft Office PowerPoint 2003 file to achieve better organization and standardization of the image selection process. Each patient was illustrated by two upper model images (baseline and post canine initial retraction), which were cut out in a standardized size, without dimensional alterations. Subsequently, this file was saved as a JPEG image and transferred to an AutoCad 2007 Autodesk software.

Measurements were performed based on the following reference points: point $P$, located at the centre of the incisive papillae, from which a line was drawn along the median palatal raphe; two other points, Crig and Clef, located at the centre of the mesiobuccal cusp of each permanent upper first molar, right and left sides, respectively. A line was traced from each of these points, perpendicularly to the median palatal raphe line, crossing it in two distinct locations, generating two other points: Clef' (representing the intersection between the line drawn from the palatal raphe and Clef point) and intersection point Crig' (between the palatal raphe and the line stemming from Crig point) (Fig 3).

The distances between the points Clef' to $\mathrm{P}$, and points Crig' to $\mathrm{P}$, crossing the median palatal raphe line are the measurements compared in both sides between the images of the models obtained at baseline and after the canine initial retraction.
Therefore, these measurements represent the position of the permanent upper first molar on both left and right sides, relative to the incisive papilla, at baseline and post canine initial retraction stages. As these distances decrease, after canine initial retraction, it indicates the amount of mesialization of the permanent upper first molar on each side (anchorage loss).

All measurements were completed and submitted to statistic analysis. In order to verify the intra-examiner systematic error a paired test was performed. For the casual error determination, Dahlberg's (Houston, 1983) formula was utilized.

$$
\begin{aligned}
\mathrm{d}= & \text { difference between the first and second mea- } \\
& \text { surements. } \\
\mathrm{n}= & \text { number of repetitions. }
\end{aligned}
$$

The results of the systematic error, measured by the paired t test and the casual error assessments are displayed on Table 1. Data were described according to the average and standard deviation shown on tables (Tables $2,3,4$ ). In order to compare Before and After stages a paired t test was used. In order to compare Mini-implant and Nance button groups a student $t$ test was applied for independent measurements. All tests considered the $5 \%$ significance level $(\mathrm{p}<0.05)$. All statistic calculations were performed by the 5.1 Statistics for Windows software (StatSoft Inc, Tulsa, USA).
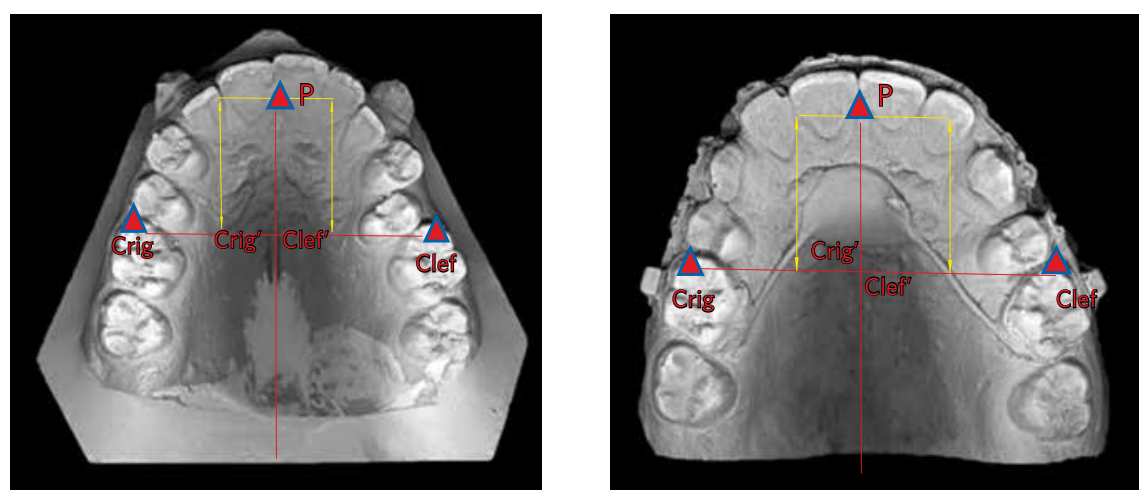

Figure 3 - Upper models (baseline and intermediate) with lines and points traced. 
Table 1 - Average, standard deviation for both measurements, paired t test, and Dahlberg's systematic and casual errors. Right side (distance between the centre of the mesiobuccal cusp of the upper permanent right first molar to point P); Left side (distance between the centre of the mesiobuccal cusp of the left permanent upper first molar to point P).

\begin{tabular}{cccccccc} 
& \multicolumn{2}{c}{ First measurement } & \multicolumn{2}{c}{ Second measurement } & t & \\
\cline { 2 - 5 } Measure & Mean & SD & Mean & SD & & \\
\hline Right side & 55.57 & 7.13 & 55.08 & 6.86 & 1.041 \\
Left side & 56.76 & 6.37 & 57.59 & 6.62 & 1.358 & $0.325 \mathrm{~ns}$ \\
\hline
\end{tabular}

ns: no statistically significant difference.

Table 2 - Average, standard deviation and comparison between Before and After measurements obtained from the models for the mini-implant group. Right Side (distance between the centre of the mesiobuccal cusp of the right permanent upper first molar to point P). Left Side (distance between the centre of the mesiobuccal cusp of the left permanent upper first molar to point P).

\begin{tabular}{|c|c|c|c|c|c|c|c|}
\hline \multirow{2}{*}{ Measure } & \multicolumn{2}{|c|}{ Beggining } & \multicolumn{2}{|c|}{ After } & \multirow{2}{*}{$\begin{array}{c}\text { Difference } \\
\text { Mean }\end{array}$} & \multirow{2}{*}{$\mathbf{t}$} & \multirow{2}{*}{$\mathbf{p}$} \\
\hline & Mean & SD & Mean & SD & & & \\
\hline Right side & 53.06 & 8.29 & 50.41 & 5.86 & -2.65 & 1.684 & $0.131 \mathrm{~ns}$ \\
\hline Left side & 52.96 & 5.70 & 51.06 & 7.21 & -1.90 & 1.080 & $0.312 \mathrm{~ns}$ \\
\hline
\end{tabular}

ns: no statistically significant difference.

Table 3 - Average, standard deviation and comparison between Before and After measurements obtained from the models for the Nance button group. Right Side (distance between the centre of the mesiobuccal cusp of the right permanent upper first molar to point P). Left Side (distance between the centre of the mesiobuccal cusp of the left permanent upper first molar to point P).

\begin{tabular}{ccccccc} 
& \multicolumn{2}{c}{ Beginning } & \multicolumn{2}{c}{ After } & \multicolumn{2}{c}{ Difference } \\
\cline { 2 - 6 } Measure & Mean & SD & Mean & SD & Mean \\
\hline Right side & 53.01 & 7.18 & 50.16 & 7.05 & -2.85 & 3.555 \\
Left side & 53.60 & 7.46 & 50.87 & 10.17 & -2.73 & $0.007{ }^{\star}$ \\
\hline
\end{tabular}

ns: no statistically significant difference *statistically significant difference $(p<0.05)$.

Table 4 - Average and standard deviation of the variations between Before and After, and comparison between mini-implant and Nance button groups. Right Side (distance between the centre of the mesiobuccal cusp of the right permanent upper first molar to point P). Left Side (distance between the centre of the mesiobuccal cusp of the left permanent upper first molar to point P)

\begin{tabular}{cccccccc}
\multirow{2}{*}{ Measure } & \multicolumn{2}{c}{ Mini-implant } & \multicolumn{2}{c}{ Nance button } & Difference & \multirow{2}{*}{ t } & \\
\cline { 2 - 5 } & Mean & SD & Mean & SD & Mean & & $0.914 \mathrm{~ns}$ \\
Right side & -2.65 & 4.73 & -2.85 & 2.41 & 0.20 & 0.109 \\
Left side & -1.90 & 5.29 & -2.73 & 5.19 & 0.83 & 0.333 & $0.743 \mathrm{~ns}$ \\
\hline
\end{tabular}

ns: no statistically significant difference.

\section{RESULTS}

Results are shown on tables 1 - 4 .

\section{DISCUSSION}

Studies based on mini-implants positioned between the roots of second pre-molars and first molars have proved to be successful for mass retraction of the anterior segment as well as during canine initial retraction. ${ }^{19,20}$

The aim of this paper was to assess the anchorage loss of permanent upper first molars after canine initial retraction between two different anchorage methods (Nance button and mini-implants).
The choice for assessing standardized stone dental models is justified by the existence of specific software capable of estimating molars anchorage loss. Canine initial retraction is an ordinary procedure within the orthodontic treatment. Many systems (appliances) are used to retract canines during space closure, which depends on many factors: type of system used, load applied, technique and periodontal condition. ${ }^{20}$

In this study, for Group A, mini-implants were inserted between the roots of permanent upper second pre-molars and first molars. Group B Nance button was employed as an anchorage system. 
The results revealed an average anchorage loss of $2,85 \mathrm{~mm}$ on the right side and $2.73 \mathrm{~mm}$ on the left side for the group with Nance button, even though the left side did not present any statistically significant difference (Table 3). These results were expected since load application is performed directly over the molars, confirming thus the null hypothesis.

It was also possible to observe by that even when bone anchorage is used, anchorage loss was detected on the upper molars for the mini-implant group (Table 2). These results demonstrate that bone anchorage cannot be ensured, since the mechanics, the intensity and control of the loads applied are still very relevant factors to be considered. ${ }^{20}$ One hypothesis to explain the anchorage loss in the mini-implant group can be possible attributed to the levelling and alignment stage, since the friction between the wire and the molar tubes might have caused the molars to rotate, as no stabilization procedure was ever done. At the end of the canine retraction molars were assessed but no conclusion was drown whether the molars had gone through rotation or tilting, as it would usually happen in any orthodontic movement.

Table 4 shows no statistically significant difference between the two groups, mini-implant and Nance button), what doesn't necessarily mean there are no differences between, but rather the absence of evidence that could support that difference. Clinically, it could be observed that there was a higher anchorage loss in the group wearing Nance button and that the interval for canine initial retraction was also longer.

Eighteen patients is quite a shy value for statistic analysis, although it could be considered quite a good number for a clinically based work. In addition, other scientific papers published used much smaller samples or even a single clinical case.

According to the present study, mini-implants cannot be considered as an absolute anchorage method. Nonetheless, studies that advocate it as the ultimate anchorage option, are actually based on clinical reports, what hinders the possibility of taking a conclusion, in other words, there are no scientific evidences. Such an argument encourages the development of standardised methodology studies. Therefore, studies that verify the effectiveness of the anchorage and the biological cost of the mini-implants are to be further developed.

\section{CONCLUSION}

After measuring and comparing models for the assessment of molars anchorage loss after canine initial retraction by means of two systems (mini-implants and Nance button) no statistically significant difference could be observed between the two groups.

\section{REFERENCES}

1. Costa A, Raffaini M, Melsen B. Microscrews as orthodontic anchorage. In J Adult Orthod Orthognath Surg. 1998;13:201-9.

2. Capelozza Filho L. Diagnóstico em Ortodontia. Maringá (PR): Dental Press; 2004.

3. Goodacre CJ, Brown DT, Roberts WE, Jeiroudi MT. Prosthodontic considerations when using implants for orthodontic anchorage. J Prosthet Dent. 1997 Feb;77(2):162-70.

4. Hong RK, Heo JM, Ha YK. Lever-arm and mini-implant system for anterior torque control during retraction in lingual orthodontic treatment Angle Orthod. 2005 Jan;75(1):129-41.

5. Janson M, Sant'Ana E, Vasconcelos W. Ancoragem esquelética com minimplantes: incorporação rotineira da técnica na prática ortodôntica. Rev Dental Press Ortodon Ortop Facial. 2006;5:85-100

6. Kyung HM, Park HS, Bae SM, Sung JH, Kim IB. Development of orthodontic microimplant for intraoral anchorage. J Clin Orthod. 2003 Jun;37(6):321-8; quiz 314.

7. Lee JS, Kim JK, Park YC, Vanarsdall RL Jr. Application of orthodontic mini-implants. Hanover Park (IL): Quintessence Books; 2007.

8. Mah J, Bergstrand F. Temporary anchorage devices: a status report. J Clin Orthod. 2005;39:132-36.

9. Park HS, Bae SM, Kyung HM, Sung JH. Simultaneous incisor retraction and distal molar movement with micro-implant anchorage. World J Orthod. 2004;5:164-71.

10. Park HS, Bae SM, Kyung HN, Sung JH. Micro-implant anchorage for treatment of skeletal Class I bialveolar protrusion. J Clin Orthod. 2001;35:417-22.

11. Park HS, Know TG, Sung JH. Microscrew implant anchorage sliding mechanics. World J Orthod. 2005;6:265-74.
12. Park HS, Know TG, Sung JH. Sliding mechanics with microscrew implant anchorage. Angle Orthod. 2004;74:703-10.

13. Reis SAB, Capelozza LF, Cardoso MA. Características cefalométricas dos indivíduos padrão I. Rev Dental Press Ortodon Ortop Facial. 2005;10:67-78.

14. Roberts WE, Arbuckle GR, Analoui M. Rate of mesial translation of mandibular molars using implant-anchored mechanics. Angle Orthod. 1996;66:331-8.

15. Roberts WE, Marshall KJ, Mozzary PG. Rapid endosseous implant utilizes as anchorage to protract molars and close an atrophic extraction site. Angle Orthod. 1990;60:135-52.

16. Roberts WE, Smith RK, Zilberman Y, Mozsary PG, Smith RS. Osseous adaptation to continuous loading of rigid endosseous implant. Am J Orthod Dentofacial Orthop. 1984;86:95-111.

17. Shapiro PA, Kokich VG. Uses of implants in orthodontics. Dent Clin North Am. 1988;32:539-50.

18. Squeff $L R$, Simonson MBA, Elias CN, Nojima LI. Caracterização de mini-implantes utilizados na ancoragem ortodôntica. R Dental Press Ortodon Ortop Facial. 2008;13:49-56.

19. Thiruvenkatachari B, Ammayappan P, Kandaswamy R. Comparison of rate of canine retraction with conventional molar anchorage and titanium implant Anchorage. Am J Orthod Dentofacial Orthop. 2008;123:30-5.

20. Thiruvenkatachari B, Pavithranada A, Rajasigamani K, Kyung HM. Comparison and measurement of the mount of anchorage loss of the molars with and without the use of implant anchorage during canine retraction. Am J Orthod Dentofacial Orthop. 2006;129:551-4. 